\title{
Precise determination of geoid height and free-air gravity anomaly at Syowa Station, Antarctica
}

\author{
Kazuo Shibuya, Koichiro Doi, and Shigeru Aoki \\ Center for Antarctic Environment Monitoring, National Institute of Polar Research, Kaga 1-9-10, Itabashi-ku, Tokyo 173-8515, Japan
}

(Received July 1, 1998; Revised December 14, 1998; Accepted December 15, 1998)

\begin{abstract}
From the International Terrestrial Reference Frame 1994 (ITRF94) coordinates of the Doppler Orbitography Radiopositioning Integrated by Satellites (DORIS) beacon marker at Syowa Station $\left(69.0^{\circ} \mathrm{S}, 39.6^{\circ} \mathrm{E}\right)$, Antarctica, we derived the ellipsoidal height of the Scientific Committee on Antarctic Research (SCAR) Global Positioning System (GPS) point as $42.240 \mathrm{~m}$ on the World Geodetic System 1984 (WGS84) associated ellipsoid of a tide free Earth at the epoch of 1993.0. Because the SCAR GPS reference mark was $21.165 \mathrm{~m}$ above the local mean sea level at the epoch of 1993.0, and because the sea surface topography is estimated as $-1.29 \mathrm{~m}$, the ground data of geoid height can be estimated as $22.37 \mathrm{~m}$ on the WGS84 ellipsoid. As for error estimate of the above value, $20-30 \mathrm{~cm}$ formal error can be assigned including $3 \mathrm{~cm}$ error from the DORIS determination, $1 \mathrm{~cm}$ error from the local geodetic tie, and the dominant 20-30 cm error from uncertain modeling of sea surface topography, etc. The EGM96 geoid model gives the synthetic geoid height of $22.10 \mathrm{~m}$ at Syowa Station; the discrepancy of $27 \mathrm{~cm}$ from the observed value is within the $36 \mathrm{~cm}$ cumulative (to the degree 360) rms (root-mean-square) error of the model. We retried similar determination at Breid Bay $\left(70.2^{\circ} \mathrm{S}, 23.8^{\circ} \mathrm{E}\right)$ and made a tie to the inland outcropped Seal Rock; the obtained value of $21.4 \mathrm{~m}$ has an overall error of $1.8 \mathrm{~m}$. These ground data can be used as test data for generating higherorder $(n, m \geq 360)$ geopotential models. With the establishment of the International Absolute Gravity Basestation Network (IAGBN) standard value at Syowa Station and gravimetric connection to the Seal Rock, ground data of free-air gravity anomalies of $0.05 \mathrm{mgal}$ accuracy at Syowa Station and $1 \mathrm{mgal}$ accuracy at Seal Rock were obtained. These gravity ground data will also serve as test data for adjusting the satellite- and/or shipborne-derived gravity anomaly maps in the region concerned.
\end{abstract}

\section{Introduction}

Determination of an accurate geoid model in the Antarctic region is important to study global geodynamics of the atmosphere/ocean and solid-earth interaction. Before GPS (Global Positioning System) development, only satellite Doppler positioning was practically applicable in the marginal sea ice zone of Antarctica to obtain the ground data of geoid height. The attained accuracy was $4 \mathrm{~m}$, restricted by the uncertainty of broadcast ephemeris positioning (e.g. the obtained value of $16.8 \mathrm{~m}$ at Breid Bay $\left(70.2^{\circ} \mathrm{S}, 23.8^{\circ} \mathrm{E}\right)$; Shibuya et al., 1991). Today, combined use of GPS and other space geodetic techniques enables us to estimate rather precise geoid height in Antarctica, and we present a result of 20-30 cm accuracy ground data obtained at Syowa Station $\left(69.0^{\circ} \mathrm{S}, 39.6^{\circ} \mathrm{E}\right)$.

The most convenient positioning in the Antarctic region, that is, GPS positioning is based on the WGS84 (World Geodetic System 1984; Defense Mapping Agency, 1987) geocentric coordinate system. Since the WGS84 reference frame usually applies the ellipsoid with the semi-major axis $a=6378137.0 \mathrm{~m}$ and the flattening factor $1 / f=$ 298.2572235630, we hereafter call the associated ellipsoid as the WGS84 ellipsoid and place the final result on it. We also re-determine ground data at Breid Bay with a precise

Copy right (c) The Society of Geomagnetism and Earth, Planetary and Space Sciences (SGEPSS); The Seismological Society of Japan; The Volcanological Society of Japan; The Geodetic Society of Japan; The Japanese Society for Planetary Sciences. ephemeris NNSS (Navy Navigation Satellite System) positioning result and make the tie to the inland Seal Rock No. 25-01 geodetic mark in East Dronning Maud Land. With these accurate geoid height data and the estimated elevation above sea level, the gravity measurements were re-analyzed to obtain free-air gravity anomalies after adjustment to the International Absolute Gravity Basestation Network (IAGBN; Boedecker and Fritzer, 1986) Syowa Station standard value.

\section{DORIS Determined Coordinates of the Beacon Marker at Syowa Station}

Figure 1 illustrates Syowa Station which is located on East Ongul Island of Lützow-Holm Bay, Antarctica. There are four reference marks by different space geodetic techniques, namely satellite Doppler point A which is identical to the classic astronomical station, DORIS (Doppler Orbitography by Radiopositioning Integrated by Satellites) beacon point D, SCAR (Scientific Committee on Antarctic Research) GPS campaign point $\mathrm{G}$ which is identical to the classic geodetic control point No. 23-16, and the VLBI (Very Long Baseline Interferometry) reference point $\mathrm{R}$ at the $11 \mathrm{~m} \mathrm{~S} / \mathrm{X}$ band paraboloid antenna. All these four reference marks are in bedrock area.

According to Boucher et al. (1996; Table T7), ITRF94 (International Terrestrial Reference Frame 1994) coordinates of the DORIS beacon marker (Photo 1) at the epoch of 1993.0 were obtained as 

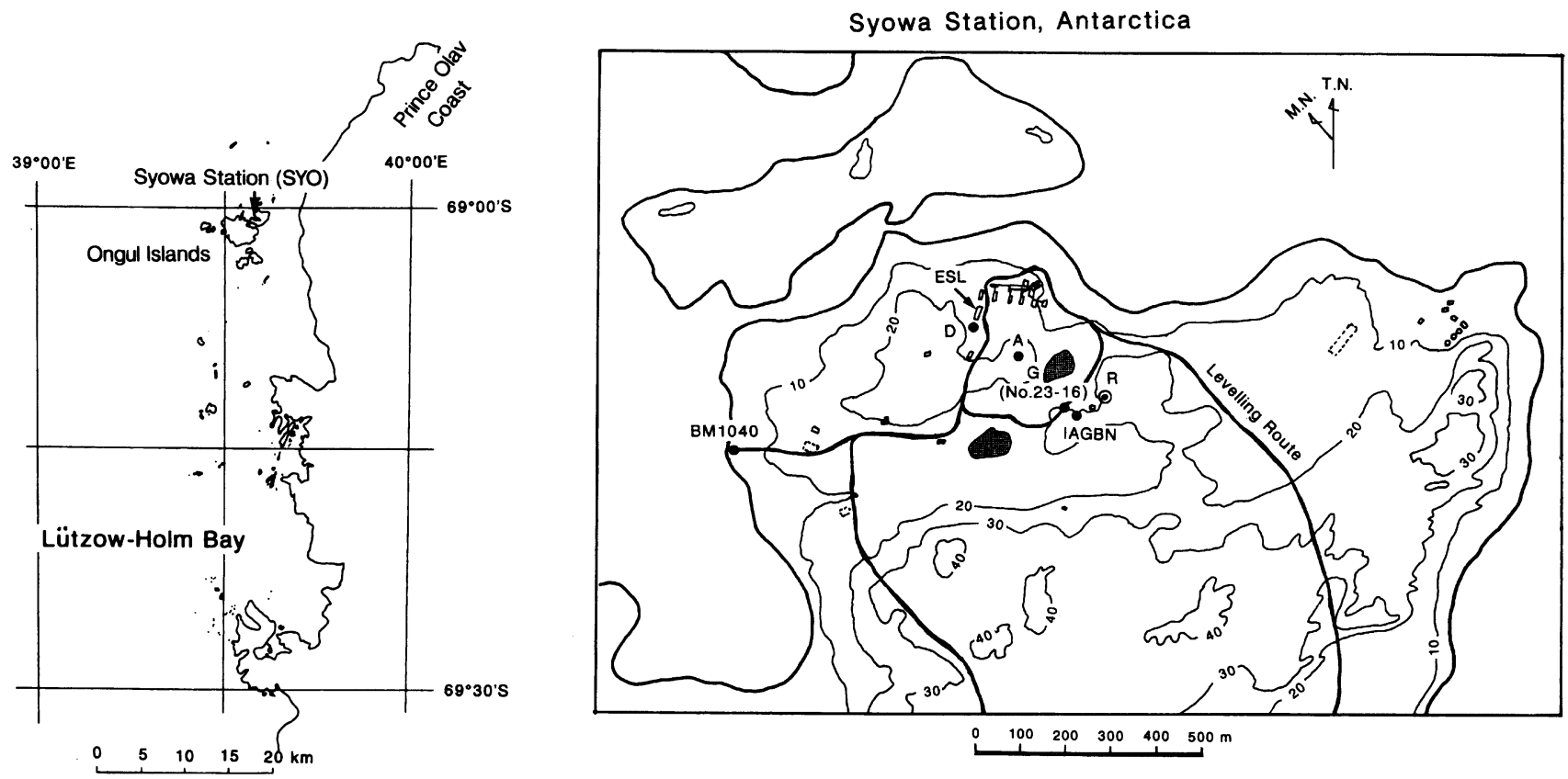

Fig. 1. Syowa Station is located on East Ongul Island of Lützow-Holm Bay, Antarctica (left). There are four reference marks by different space geodetic techniques around the main facilities (right). All the four reference marks are in bedrock area. As for explanation of the abbreviated marks and facilities, see text.

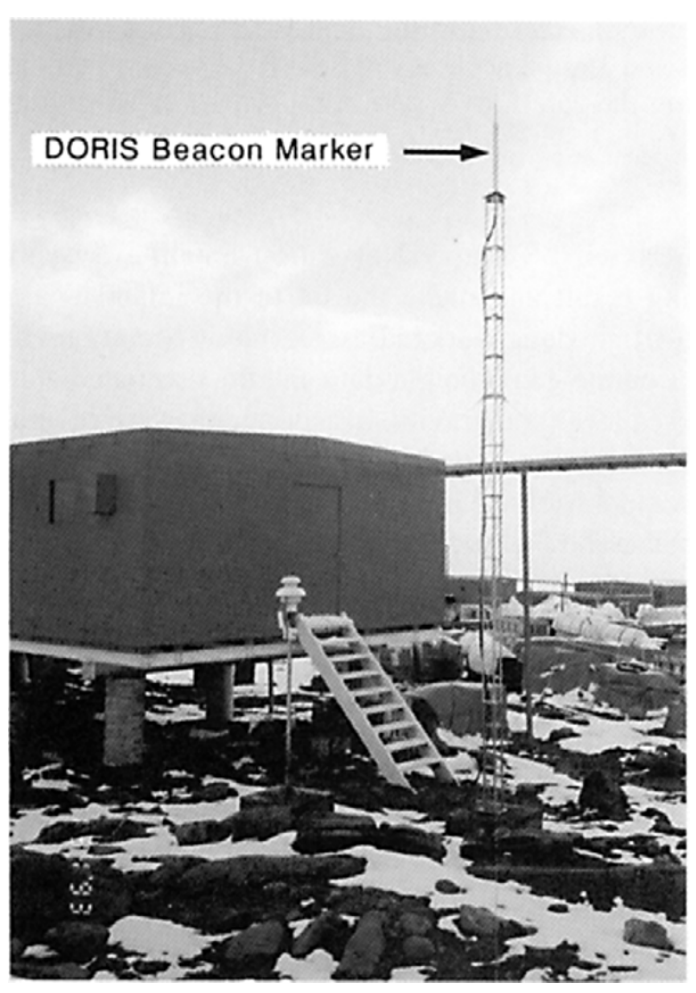

Photo 1. DORIS beacon pier installed near the Earth Science Laboratory (ESL; see Fig. 1) of Syowa Station.

$$
\begin{aligned}
& X_{\mathrm{D}}=1766498.873 \mathrm{~m}, \quad Y_{\mathrm{D}}=1460274.430 \mathrm{~m}, \\
& Z_{\mathrm{D}}=-5932211.730 \mathrm{~m},
\end{aligned}
$$

with an uncertainty of $3 \mathrm{~cm}$ for each coordinate. It is noted that Eq. (1) is given in the tide free system (C. Boucher, 1997; personal communication).

Kanao et al. (1995) estimated the offset vector $\overrightarrow{\mathrm{DG}}$ as

$$
\overrightarrow{\mathrm{DG}}=(-316.322 \mathrm{~m}, 62.323 \mathrm{~m},-73.692 \mathrm{~m})
$$

by combined use of two-frequency GPS relative positioning and classic geodetic surveying within an overall error of $1 \mathrm{~cm}$. Thus the DORIS-determined ITRF94 coordinates of the SCAR GPS point were estimated as

$$
\begin{aligned}
& X_{\mathrm{G}, \text { DORIS }}=1766498.873-316.322=1766182.551 \mathrm{~m}, \\
& Y_{\mathrm{G}, \text { DORIS }}=1460274.430+62.323=1460336.753 \mathrm{~m}, \quad(3) \\
& Z_{\mathrm{G}, \text { DORIS }}=-5932211.730-73.692=-5932285.422 \mathrm{~m} .
\end{aligned}
$$

\section{WGS84 Coordinates of the SCAR GPS Point in a Tide Free System}

It is well known that the WGS84 coordinate system has a slight inconsistency against the ITRF coordinate system (e.g. Abusali et al., 1995), and we apply a summary of seven parameter transformations by Tobita (1997) to convert Eq. (3) into the WGS84 coordinate values:

$$
\begin{aligned}
\left(\begin{array}{l}
X \\
Y \\
Z
\end{array}\right)_{\mathrm{WGS} 84}= & \left(\begin{array}{c}
0.078 \\
-0.505 \\
-0.253
\end{array}\right)+\left(1.0-1.01 \times 10^{-8}\right) \\
& \cdot\left(\begin{array}{ccc}
1 & \delta \omega & -\delta \psi \\
-\delta \omega & 1 & \delta \varepsilon \\
\delta \psi & -\delta \varepsilon & 1
\end{array}\right)\left(\begin{array}{l}
X \\
Y \\
Z
\end{array}\right)_{\text {ITRF94 }},
\end{aligned}
$$

where $\delta \omega=-3.394 \times 10^{-8}, \delta \psi=1.454 \times 10^{-9}$ and $\delta \varepsilon=-8.872 \times 10^{-8}$ are given as the rotational parameters. It is noted that $\delta \omega$ in the original formula of McCarthy 


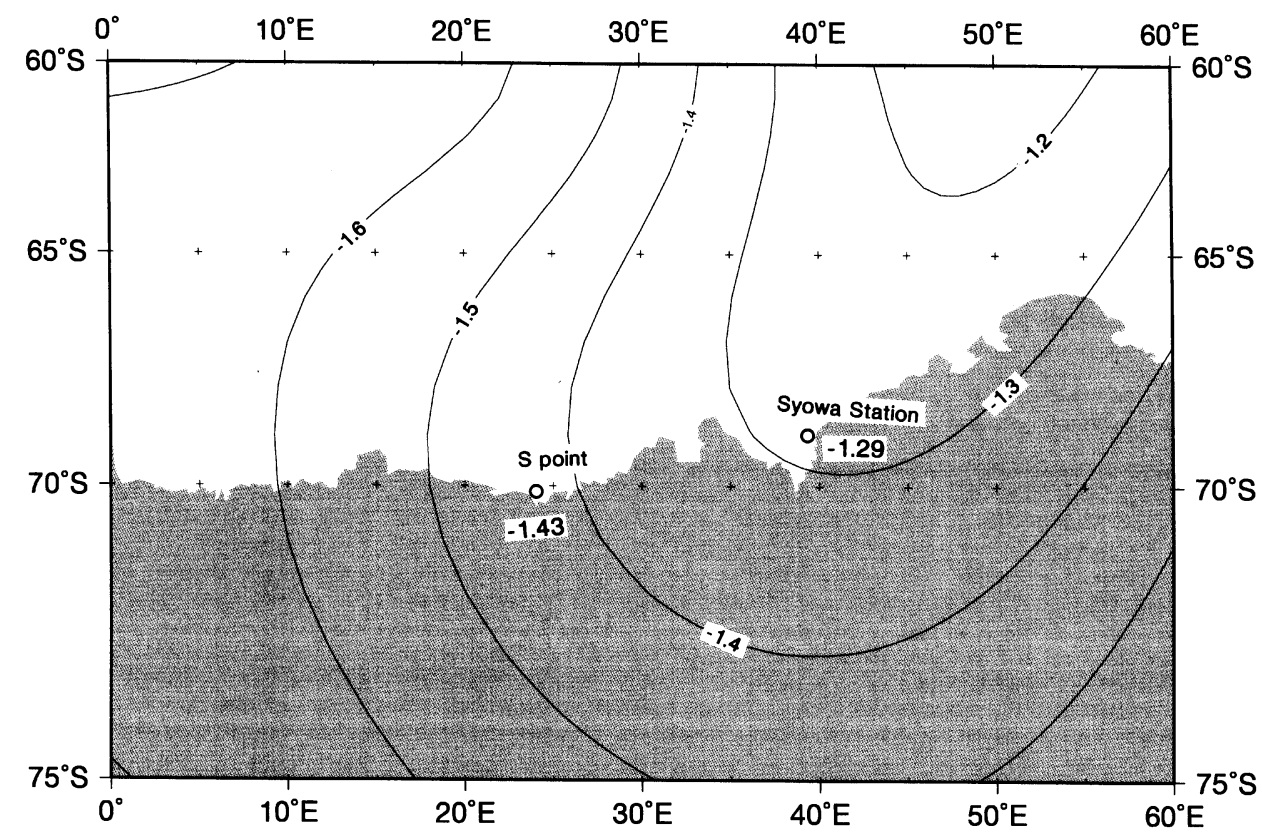

Contour: $0.1 \mathrm{~m}$

Fig. 2. Sea surface topography around Syowa Station in the region bounded by $\left(0^{\circ}-60^{\circ} \mathrm{E}, 60^{\circ} \mathrm{S}-75^{\circ} \mathrm{S}\right)$ after the degree 20 expansion model as part of the EGM96 geoid modeling (Lemoine et al., 1997). Contour interval is $10 \mathrm{~cm}$. Calculated based on the information from the NIMA (National Imagery and Mapping Agency) web site.

(1992) has opposite sign. Application of Eq. (4) to Eq. (3) and subsequent transformation into the WGS84 geodetic coordinates results in

$$
\begin{aligned}
& \phi_{\mathrm{G}}=69^{\circ} 00^{\prime} 24.600^{\prime \prime} \mathrm{S}, \quad \lambda_{\mathrm{G}}=39^{\circ} 35^{\prime} 06.152^{\prime \prime} \mathrm{E}, \\
& H_{\mathrm{G}}=42.240 \mathrm{~m}
\end{aligned}
$$

at the epoch of 1993.0. The uncertainty of the seven parameters in Eq. (4) may introduce about $2 \mathrm{~cm}$ uncertainty into the ellipsoidal height $H_{\mathrm{G}}$ of Eq. ( $\left.4^{\prime}\right)$.

\section{Reduction to the Local Mean Sea Level}

In East Ongul Island, there is a leveling route in the form of a closed loop from the bench mark BM1040 at the tide gauge station of Syowa Station (Fig. 1), which passes through the No. 23-16 geodetic mark, that is, the SCAR GPS point. Several Japanese Antarctic Research Expeditions (JARE-23, -33 and -37 ) repeated a first-order leveling survey within the closure error of $3 \mathrm{~mm}$, and the height difference between the bench mark BM1040 and the SCAR GPS point, $\Delta h$, at the epoch of 1992.0 was obtained as

$$
\Delta h=h_{\mathrm{No} .23-16}-h_{\mathrm{BM} 1040}=18.8165 \mathrm{~m} .
$$

Another uncertainty of the elevation $h_{\text {No. 23-16 }}$ above sea level comes from uncertain/unstable determination of the local mean sea level. Although the elevation of BM1040 was adopted as

$$
h_{\mathrm{BM} 1040}=2.3380 \mathrm{~m}
$$

above the local mean sea level at the epoch of 1992.0 when the leveling survey was made by JARE-33 (January 5-10,
1992), Odamaki et al. (1991) indicate apparent sea level fall with a rate of $1.0 \mathrm{~cm} /$ year. From Eqs. (5) and ( $\left.5^{\prime}\right)$, we estimate

$$
\begin{aligned}
h_{\text {No. 23-16 }} & =d h+h_{\mathrm{BM} 1040}+(\text { apparent rise }) \\
& \sim 18.816 \mathrm{~m}+2.338 \mathrm{~m}+0.01 \mathrm{~m}=21.16 \mathrm{~m}
\end{aligned}
$$

at the epoch of 1993.0.

\section{Obtained Ground Data of Geoid Height at Syowa Station}

It is noted that local mean sea level is not identical to the global geoid surface, and sea surface topography has to be corrected for in order to estimate the geoidal undulation. For example, Rapp et al. (1991) modeled the sea surface topography $\zeta$ for the global ocean using the GEOSAT data. An improved sea surface topography expanded to degree and order 20 is now available from the information at the web site http://cddis.gsfc.nasa.gov/egm96/general_info/ readme.sst_egm96_topex_ers1, and Fig. 2 illustrates the calculated $0.1 \mathrm{~m}$ model contours around Lützow-Holm Bay. We obtain $\zeta$ at Syowa Station as

$$
\zeta_{\mathrm{SYO}}=-1.29 \mathrm{~m} \text {. }
$$

From Eqs. (4'), (6) and (7), the observed geoid height at Syowa Station can be deduced as

$$
\begin{aligned}
N_{\mathrm{SYO}, \mathrm{obs}} & =H_{\mathrm{G}}-h_{\mathrm{No.} 23-16}-\zeta_{\mathrm{SYO}} \\
& =42.24-21.16+1.29=22.37 \mathrm{~m}
\end{aligned}
$$

on the WGS84 ellipsoid.

Table 1 summarizes the error items and their estimates within the obtained value of $N_{\text {SYO, obs }}$. The items (a), (b) 


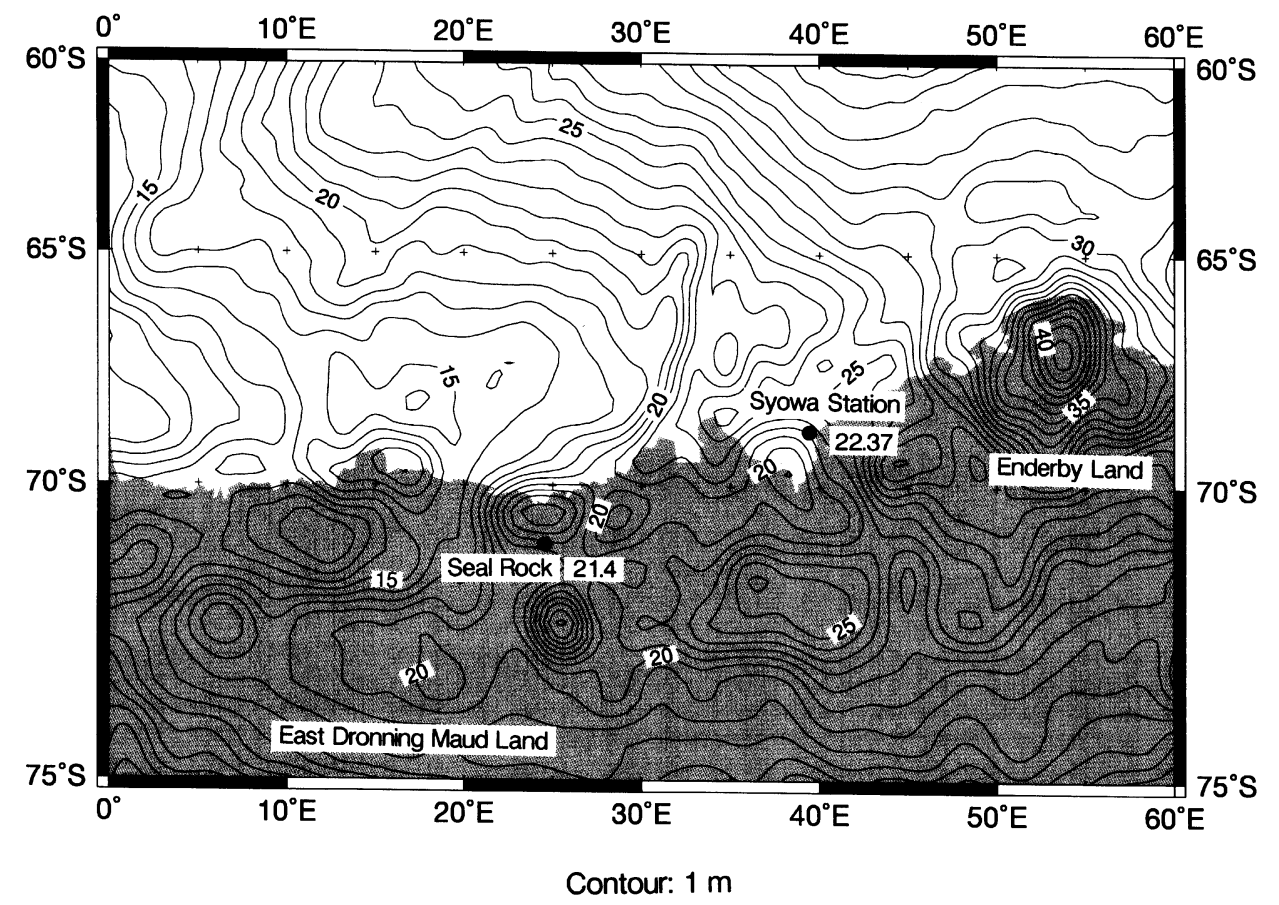

Fig. 3. The EGM96 model geoid undulations (Lemoine et al., 1997) around Syowa Station for the region bounded by $\left(0^{\circ}-60^{\circ} \mathrm{E}, 60^{\circ} \mathrm{S}-75^{\circ} \mathrm{S}\right)$ on the WGS 84 ellipsoid. Contour interval is $1 \mathrm{~m}$. Solid circles are observed ground data obtained in this analysis.

Table 1. Error estimate of the observed geoid height $N_{\mathrm{SYO} \text {,obs }}$ at Syowa Station.

\begin{tabular}{lr}
\hline \multicolumn{1}{c}{ Error item } & Estimate \\
\hline (a) DORIS beacon marker determination & $3 \mathrm{~cm}$ \\
(b) Local geodetic tie to a ground reference mark & $1 \mathrm{~cm}$ \\
(c) Seven parameter coordinate transformation & $2 \mathrm{~cm}$ \\
(d) Uncertainty of local mean sea level including & $1 \mathrm{~cm}$ \\
& \\
(e) Discrepancy of local mean sea level from & $20-30 \mathrm{~cm}$ \\
& \\
\hline
\end{tabular}

Formal overall error is $\left(\mathrm{a}^{2}+\mathrm{b}^{2}+\mathrm{c}^{2}+\mathrm{d}^{2}+\mathrm{e}^{2}\right)^{1 / 2} \lesssim 30 \mathrm{~cm}$.

and (d) are directly related with observations at the site, and their overall effect is within $4 \mathrm{~cm}$. As for (e), we have an estimated error of $20-30 \mathrm{~cm}$, which is thus dominant in the overall formal error of 20-30 cm. The discrepancy of local mean sea level from the global sea surface topography is not separated from the cumulative rms error in geoid undulation, and improvement of sea surface topography must proceed in parallel with the improvement of the Earth's gravitational potential modeling.

\section{Comparison with the Model Geoid}

Figure 3 illustrates the EGM96 model geoid undulations (Lemoine et al., 1997) in the region concerned, which are calculated from the spherical harmonic coefficients to degree and order 360 . Since these coefficients are developed in the tide free system for an ideal Earth ellipsoid of $a=$ $6378136.46 \mathrm{~m}$ and $1 / f=298.25765$, a correction term of $-0.53 \mathrm{~m}$ after e.g. Rapp (1997), has to be applied to have values adjusted on the WGS84 ellipsoid.

One of the significant characteristics is the regional mound of $13 \mathrm{~m}$ high over Enderby Land, which also corresponds to regional aeromagnetic anomaly highs of $>500 \mathrm{nT}$ amplitude (Golynsky et al., 1996) and MAGSAT crustal magnetic anomalies of $10 \mathrm{nT}$ amplitude (Takenaka et al., 1991). Lützow-Holm Bay is located to the western side of this mound, and the model value at Syowa Station can be calculated as

$$
N_{\text {SYO,EGM96 }}=22.10 \mathrm{~m} \text {. }
$$

The difference between the observed value and the model value results in

$$
\begin{aligned}
\delta N_{\mathrm{SYO}, \mathrm{EGM} 96} & =N_{\mathrm{SYO}, \mathrm{obs}}-N_{\mathrm{SYO}, \mathrm{EGM} 96} \\
& =22.37-22.10=0.27 \mathrm{~m} .
\end{aligned}
$$

The obtained discrepancy of Eq. (10) is within the expected range of residual undulations above degree 360 , as the standard deviation of the discrepancies between the GPS/leveling geoid heights of the $25-\mathrm{km}$ spacing GPS network stations (806 stations) of the Geographical Survey Institute, Japan and the corresponding EGM96 geoid model values can be estimated as $38.5 \mathrm{~cm}$ (Y. Kuroishi, 1998; personal communication).

According to Lemoine et al. (1997), the observed geoid heights from GPS/leveling generally have discrepancies of 20-50 cm from the EGM96 geoid model for the regions including Europe $(8 \mathrm{~cm})$, Australia $(-80 \mathrm{~cm})$ and Scandinavia $(19 \mathrm{~cm})$, where the estimate in the parenthesis indicates an 
Table 2. Comparison of ground data of geoid height at Syowa Station with synthetic values calculated from the EGM96 and OSU91A global geopotential models (upper part), and the free-air gravity anomalies (lower part). See Sections 6 and 7.

(a) Geoid height

\begin{tabular}{lcc}
\hline $\begin{array}{c}\text { Geopotential model } / \\
\text { Associated ellipsoid }\end{array}$ & $\begin{array}{c}\text { Synthetic geoid height } \\
N_{\text {SYO,model }}{ }^{*}\end{array}$ & $\begin{array}{c}\text { Residual from the ground data } \\
\delta N_{\text {SYO,model }}{ }^{+}\end{array}$ \\
\hline EGM96 $(n, m \leq 360)$ & $22.10 \mathrm{~m}$ & $+0.27 \mathrm{~m}$ \\
& \\
&
\end{tabular}

(b) Free-air gravity anomaly

\begin{tabular}{lccccc}
\hline Site name & $\begin{array}{c}\text { Observed gravity } \\
\text { value }(\mathrm{mgal})\end{array}$ & $\begin{array}{c}\text { Station } \\
\text { coordinates }\end{array}$ & $\begin{array}{c}\text { Height above } \\
\text { sea level (m) }\end{array}$ & $\begin{array}{c}\text { Normal gravity } \\
\text { (mgal) }\end{array}$ & $\begin{array}{c}\text { Free-air anomaly } \\
\text { (mgal) }\end{array}$ \\
\hline IAGBN & 982524.324 & Eq. $(11)$ & 21.492 & 982550.451 & -18.64 \\
SCAR GPS & 982524.540 & Eq. $\left(4^{\prime}\right)$ & 21.165 & 982550.458 & -18.53 \\
\hline
\end{tabular}

average of more than 30 data of model minus observed values.

For another comparison, model undulations with the OSU91A spherical harmonics (Rapp et al., 1991; $n, m \leq$ 360) were calculated and adjusted on the WGS84 ellipsoid, and comparison with the observed value was made as summarized in the upper part of Table 2. The apparent difference of the OSU91A associated model value from the observed value of Eq. (8) resulted in $-0.58 \mathrm{~m}$ at Syowa Station; the magnitude of discrepancy is larger than that for the EGM96 model. Similar comparison of GPS/leveling ground data with the OSU91A model geoid gave an overall discrepancy of 32-95 cm for the same regions discussed above (Lemoine et al., 1997).

\section{Free-Air Gravity Anomaly}

Together with geoid height control data, precisely determined free-air gravity anomaly data in the Antarctic region will provide useful test data for global geopotential modeling or gravity anomaly contouring. Although previous gravity measurements in the Japanese Antarctic research area were based on relative spring-type (e.g. LaCoste \& Romberg) gravimeters, absolute gravimeter observations have recently been made at the International Absolute Gravity Basestation Network (IAGBN) Syowa Station (IAGBN-A \#0417 by Boedecker and Fritzer, 1986; see Fig. 1), where the station coordinates are given as

$$
\begin{aligned}
& \phi_{\mathrm{IAGBN}}=69^{\circ} 00^{\prime} 24.245^{\prime \prime} \mathrm{S}, \\
& \lambda_{\mathrm{IAGBN}}=39^{\circ} 35^{\prime} 08.498^{\prime \prime} \mathrm{E}, \quad \text { and } \\
& h_{\mathrm{IAGBN}}=21.492 \mathrm{~m},
\end{aligned}
$$

after the geodetic survey results by M. Iwata of JARE-39 (Jan. 1998).

Kaminuma and Tsukahara (1996) adopted the gravity value by Yamamoto (1996) after considering a small overlooked correction, which was obtained with an FG5\#104/GSI1994.09 gravimeter (notation after Boedecker, 1991), as the standard gravity value at the IAGBN Syowa Station:

$$
g_{\text {Syowa, } \mathrm{IAGBN}}=982524.327 \pm 0.015 \mathrm{mgal},
$$

where $1 \mathrm{mgal}=10^{-5} \mathrm{~m} / \mathrm{s}^{2}$.

The gravity value at the nearby SCAR GPS point (No. 2316 geodetic mark in Fig. 1) connected by using a LaCosteRomberg gravimeter was determined as

$$
g_{\text {Syowa }, \mathrm{G}}=982524.540 \mathrm{mgal} .
$$

In order to obtain free-air gravity anomalies, reduction of normal gravity values after the Geodetic Reference System 1980 standard gravity formula (Moritz, 1980) and the associated free-air reduction are required. It must be noted that the vertical gradient of normal gravity can be expressed as

$$
\begin{aligned}
\gamma & =-0.3087798 \times\left(1-1.4281321 \times 10^{-3} \sin ^{2} \phi\right. \\
& \left.+1.616411 \times 10^{-6} \sin ^{2} 2 \phi\right) \\
= & -0.30839 \mathrm{mgal} / \mathrm{m}
\end{aligned}
$$

at latitudes of around $69^{\circ} \mathrm{S}$, which slightly differs from the usually adopted value of $-0.3086 \mathrm{mgal} / \mathrm{m}$ at mid latitudes.

Thus, we can estimate refined free-air gravity anomalies in Syowa Station as -18.64 mgal (IAGBN station) and -18.53 


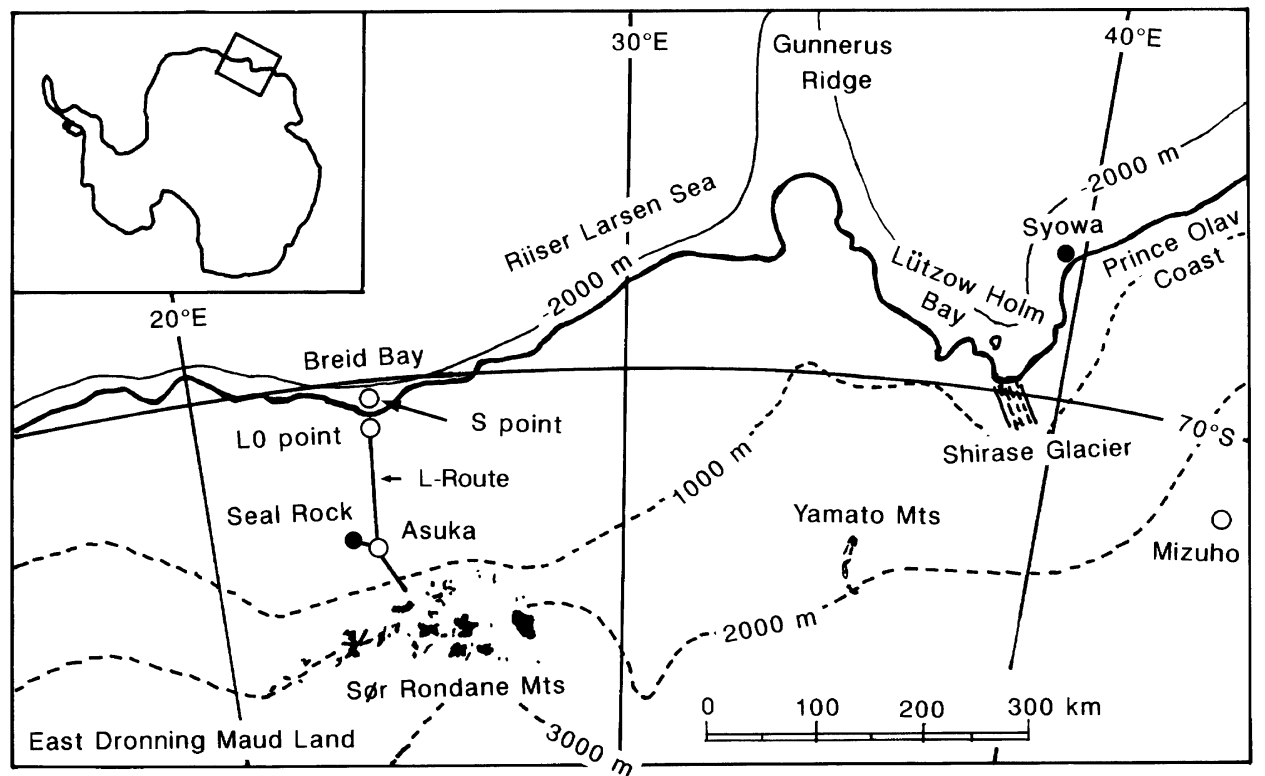

Fig. 4. Determination of observed geoid height in Dronning Maud Land revisited; this figure is a revision of Fig. 2 by Shibuya et al. (1991). Solid circles indicate control marks on the outcrop area, while open circles indicate marks temporarily placed on the sea/ice area and change their position with time.

mgal (SCAR GPS point), respectively as summarized in the lower part of Table 2. Since the accuracy of the station coordinates are within $5 \mathrm{~cm}$ for both the latitudinal and height directions, and since the measurement errors of gravity are within $0.02 \mathrm{mgal}$, better than $0.05 \mathrm{mgal}$ error is definitely assured for the obtained free-air gravity anomaly values.

\section{Determination in East Dronning Maud Land Revisited}

As there are few ground data of geoid height or gravity anomaly with reliable error budgets in the Antarctic region, re-analysis of Breid Bay data (Shibuya et al., 1991) and their tie to the inland outcrop area of the East Dronning Maud Land region has benefits, even though the overall error is larger by one-order of magnitude than that at Syowa Station.

\subsection{Breid Bay data revisited and tied to Seal Rock}

Shibuya et al. (1991) applied broadcast ephemeris satellite Doppler positioning result at L0 point (Fig. 4) to estimate the geoid height at $\mathrm{S}$ point in Breid Bay, but precise ephemeris NNSS positioning gave revised coordinates of the antenna phase center as

$$
\begin{aligned}
& X_{\mathrm{L} 0}=1956937.54 \mathrm{~m}, \quad Y_{\mathrm{L} 0}=866768.16 \mathrm{~m}, \\
& Z_{\mathrm{L} 0}=-5988362.84 \mathrm{~m}
\end{aligned}
$$

or

$$
\begin{aligned}
& \phi_{\mathrm{L} 0}=70^{\circ} 27^{\prime} 15.27^{\prime \prime} \mathrm{S}, \quad \lambda_{\mathrm{L} 0}=23^{\circ} 53^{\prime} 22.36^{\prime \prime} \mathrm{E}, \\
& H_{\mathrm{L} 0}=190.01 \mathrm{~m}
\end{aligned}
$$

in the WGS84 coordinate system (M. Kumar, 1991; personal communication) with an error of $1.5 \mathrm{~m}$ for the ellipsoidal height. Since $\mathrm{S}$ point is in the sea ice region and since L0 point is on the flowing ice sheet, geodetic tie to the inland nearest outcrop area of Seal Rock (Photo 2) was necessary to maintain the control mark.
We can update the observed geoid height at $\mathrm{S}$ point $\left(70^{\circ} 11^{\prime} 58.48^{\prime \prime} \mathrm{S}, 23^{\circ} 46^{\prime} 35.46^{\prime \prime} \mathrm{E}\right)$ in Breid Bay as

$$
\begin{aligned}
N_{\text {Spoint,obs }} & =H_{\mathrm{L} 0}-h-p+r-\zeta_{\text {Spoint }} \\
& =190.0-162.5-7.4+0.72+1.43 \\
& =22.25 \sim 22.3 \mathrm{~m}
\end{aligned}
$$

on the WGS84 ellipsoid, where each parameter symbol corresponds to Eq. (1) and Table 4 of Shibuya et al. (1991), see Table 3. In Eq. (16), other related observational data are not necessary to be revised except $H_{\mathrm{L} 0}$ and inclusion of $\zeta_{\text {Spoint }}$. As shown in Fig. 2, sea surface topography is declined to west at latitude of $70^{\circ} \mathrm{S}$ in the region concerned, and the difference between Syowa Station and S point is about $14 \mathrm{~cm}$.

Since the slant distance between $\mathrm{S}$ point (Breid Bay) and Seal Rock (East Dronning Maud Land) is comparatively short (120 km, see Fig. 4), the difference of the geoid undulation values from the global geoid model may represent the local geoid difference. According to the EGM96 geoid model, the undulation difference can be calculated as $0.82 \mathrm{~m}$ between S point (high) and Seal Rock (low), so that the pseudo-observed geoid height $N_{\text {Seal,obs }}$ at Seal Rock may be estimated as

$$
N_{\text {Seal, obs }}=22.25-0.82 \sim 21.4 \mathrm{~m} \text {. }
$$

As for error assessment listed in Table 3, uncertainty (a) from NNSS positioning can be considered as dominating over other (b) and (c) factors including truncation error (g) of the geoid model, and we put an overall error of $1.8 \mathrm{~m}$ in $N_{\text {Seal,obs }}$ of Eq. (17).

\subsection{Station coordinates of Seal Rock}

Although direct connection was not operationally possible, NNSS translocation between L0 point and Asuka Station (Fig. 4, Photo 2) which were both on the ice sheet, and onefrequency and 4 channel GPS relative positioning between 


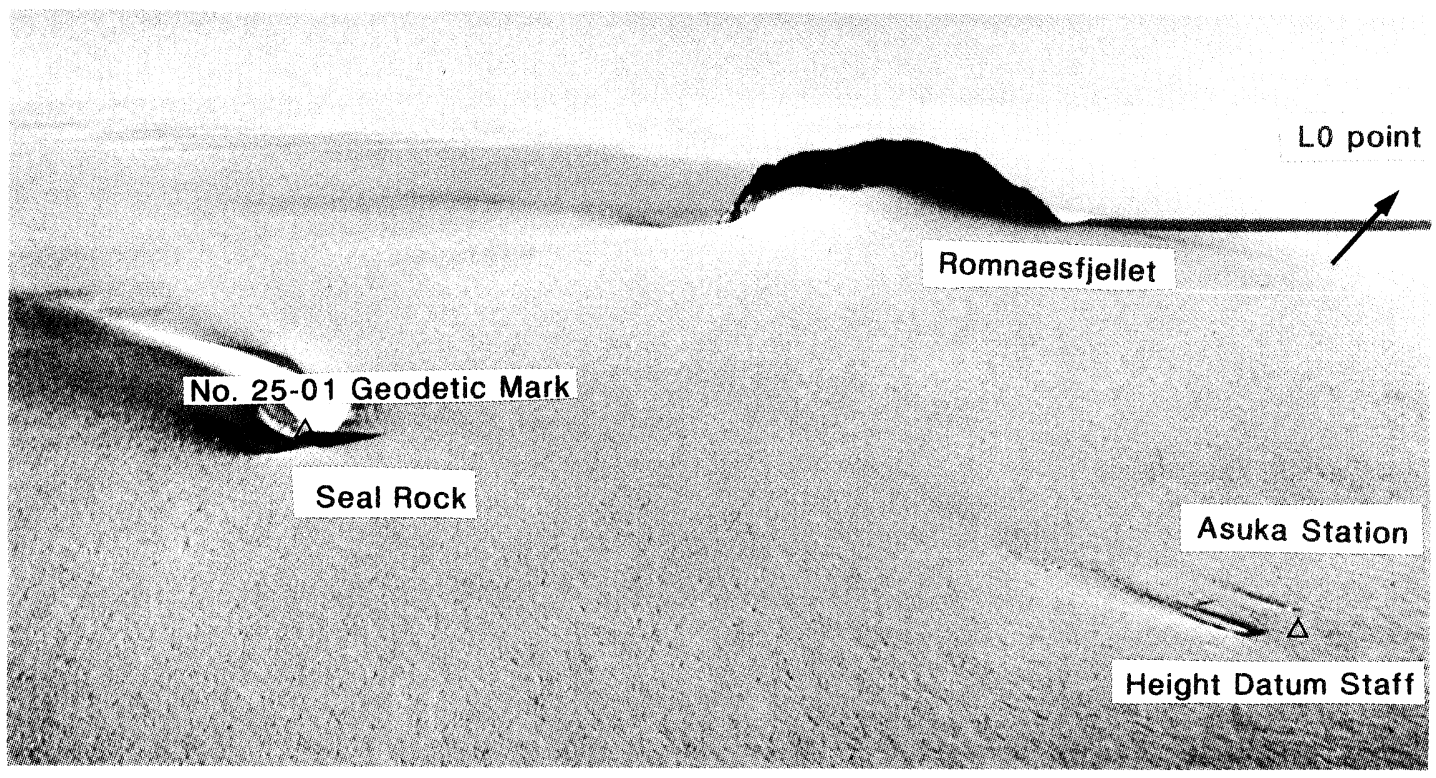

Photo 2. Geodetic tie from L0 point at Breid Bay on the ice sheet to No. 25-01 geodetic mark at Seal Rock on the inland outcrop area through Asuka Station on the ice sheet, was necessary to maintain the ground mark.

Table 3. Determination of pseudo-observed geoid height at Seal Rock. Error estimate of Table 4 by Shibuya et al. (1991) was updated with inclusion of sea surface topography data and truncation error associated with the shift from S point to Seal Rock.

\begin{tabular}{|c|c|c|c|c|}
\hline Item & Observation/Model & Parameter symbol & $\begin{array}{l}\text { Estimate } \\
\text { (m) }\end{array}$ & $\begin{array}{l}\text { Standard error } \\
\text { (m) }\end{array}$ \\
\hline (a) & Ellipsoidal height & $H_{\mathrm{L} 0}$ & 190.0 & 1.5 \\
\hline (b) & $\begin{array}{l}\text { Height difference } \\
\text { between } \mathrm{L} 0 \text { and } \mathrm{S} \text { point }\end{array}$ & $h$ & 162.5 & 0.3 \\
\hline (c) & $\begin{array}{l}\text { Separation of S point } \\
\text { from the local mean sea level }\end{array}$ & $p$ & 7.4 & 0.3 \\
\hline (d) & Antenna offset & $r$ & 0.72 & 0.03 \\
\hline (e) & Sea surface topography & $\zeta_{\text {Spoint }}$ & -1.43 & $0.2-0.3$ \\
\hline \multicolumn{5}{|c|}{$N_{\text {Spoint }, \text { obs }}=H_{\mathrm{L} 0}-h-p+r-\zeta_{\text {Spoint }}=22.25 \mathrm{~m}$ by Eq. $(16)$} \\
\hline (f) & Geoid height at S point & $N_{\text {Spoint,obs }}$ & 22.25 & \\
\hline (g) & $\begin{array}{l}\text { Geoidal undulation difference } \\
\text { between S point and Seal Rock }\end{array}$ & - & 0.82 & $0.8^{*}$ \\
\hline (h) & $\begin{array}{l}\text { Pseudo-observed geoid } \\
\text { height at Seal Rock }\end{array}$ & $N_{\text {Seal }, \text { obs }}$ & 21.4 & $1.8^{* *}$ \\
\hline
\end{tabular}

*We put the same magnitude of the undulation difference as the standard error.

** Formal overall error is $\left(\mathrm{a}^{2}+\mathrm{b}^{2}+\mathrm{c}^{2}+\mathrm{d}^{2}+\mathrm{e}^{2}+\mathrm{g}^{2}\right)^{1 / 2}<1.8 \mathrm{~m}$.

Asuka Station and Seal Rock No. 25-01 geodetic mark on the outcrop area, were made by JARE-28 (in 1987). The obtained offset vector from L0 point satellite Doppler antenna phase center to that of Asuka Station, denoted as $\overrightarrow{\mathrm{LOAsuka}}$ in the WGS84 geocentric coordinate system, can be expressed as

$$
\begin{aligned}
& \overrightarrow{\text { L0Asuka }} \\
& \quad=(-106497.57 \mathrm{~m},-37834.35 \mathrm{~m},-39655.10 \mathrm{~m}) .
\end{aligned}
$$

Doppler and GPS antenna phase centers, WGS84 geocentric coordinates of the GPS antenna phase center at Asuka Station (height datum staff mark) can be expressed as

$$
\begin{aligned}
& X_{\mathrm{ASK}}=1850438.47 \mathrm{~m}, \quad Y_{\mathrm{ASK}}=828932.65 \mathrm{~m}, \\
& Z_{\mathrm{ASK}}=-6028019.19 \mathrm{~m},
\end{aligned}
$$

or

$$
\begin{aligned}
& \phi_{\mathrm{ASK}}=71^{\circ} 31^{\prime} 29.14^{\prime \prime} \mathrm{S}, \quad \lambda_{\mathrm{ASK}}=24^{\circ} 07^{\prime} 50.65^{\prime \prime} \mathrm{E}, \\
& H_{\mathrm{ASK}}=979.1 \mathrm{~m} .
\end{aligned}
$$


Table 4. Summary of free-air gravity anomalies in East Dronning Maud Land as referred to the IAGBN site at Syowa Station.

\begin{tabular}{|c|c|c|c|c|c|}
\hline Site name & $\begin{array}{c}\text { Observed gravity } \\
\text { value }^{(\mathrm{a})} \\
g_{\text {obs }}(\mathrm{mgal})\end{array}$ & $\begin{array}{c}\text { Station } \\
\text { coordinates }\end{array}$ & $\begin{array}{l}\text { Height above } \\
\text { sea level }^{(\mathrm{b})} \\
h(\mathrm{~m})\end{array}$ & $\begin{array}{l}\text { Normal } \\
\text { gravity }^{(\mathrm{c})} \\
\gamma(\mathrm{mgal})\end{array}$ & $\begin{array}{c}\text { Free-air } \\
\text { anomaly }^{(\mathrm{d})} \\
\delta g(\mathrm{mgal})\end{array}$ \\
\hline Seal Rock & 982402.817 & Eq. $\left(21^{\prime}\right)$ & $974.6 \mathrm{~m}$ & 982695.786 & 8.4 \\
\hline Asuka Station & 982384.544 & Eq. $\left(19^{\prime}\right)$ & $956.5 \mathrm{~m}^{*}$ & 982695.773 & -15.5 \\
\hline L0 point & 982718.143 & Eq. $\left(15^{\prime}\right)$ & $166.2 \mathrm{~m}$ & 982635.886 & 134.4 \\
\hline
\end{tabular}

\footnotetext{
(a) Observed gravity values $g_{\text {obs }}$ by Fukuda (1986) were adjusted to the new gravity standard value at the ESL by Eq. (25), which was refined by the value of Eq. (12) at the IAGBN Syowa Station.

(b) Height above sea level was calculated by subtracting the geoid height from the observed ellipsoidal height, e.g. Eq. (22) for Seal Rock.

*In order to obtain the elevation of snow surface above sea level, offset reduction of $1.2 \mathrm{~m}$ was furthermore necessary to the datum point at the top of the Asuka height datum staff; so that, $h_{\mathrm{ASK}}=979.1-1.2-21.4=956.5 \mathrm{~m}$.

${ }^{(c)}$ Normal gravity value $\gamma$ was calculated with the Gravity Formula 1980 using the Somigliana exact expression.

${ }^{\text {(d) }}$ Free air anomaly $\delta g$ was calculated by the following equation
}

$$
\delta g=g_{\text {obs }}-\gamma+0.30839 h+0.86-0.0000965 h,
$$

where $h$ is the height above sea level.

In March 16, 1987, GPS relative positioning was made during 12:38-13:38 UT between Asuka height datum staff mark and Seal Rock No. 25-01 geodetic mark. Since characteristics of the receivers, observation conditions, and the method of the analysis are the same as described in Shibuya et al. (1991), only the obtained offset vector $\overrightarrow{\text { AsukaSeal }}$ is described here as

$$
\overrightarrow{\text { AsukaSeal }}=(929.77 \mathrm{~m},-2123.12 \mathrm{~m},-25.19 \mathrm{~m}) .
$$

After correcting height offset $(1.30 \mathrm{~m})$ of the GPS antenna, the final WGS84 coordinates of the Seal Rock No. 25-01 geodetic mark are expressed as

$$
\begin{aligned}
& X_{\text {Seal }}=1851367.86 \mathrm{~m}, \quad Y_{\text {Seal }}=826809.37 \mathrm{~m}, \\
& Z_{\text {Seal }}=-6028043.14 \mathrm{~m},
\end{aligned}
$$

or

$$
\begin{aligned}
& \phi_{\text {Seal }}=71^{\circ} 31^{\prime} 29.95^{\prime \prime} \mathrm{S}, \quad \lambda_{\text {Seal }}=24^{\circ} 03^{\prime} 54.87^{\prime \prime} \mathrm{E}, \\
& H_{\text {Seal }}=996.0 \mathrm{~m} .
\end{aligned}
$$

\subsection{Free-air gravity anomaly ground data}

Geodetically, a more useful result may be an accurate deduction of $h_{\text {Seal }}$, that is, the elevation of Seal Rock No. 25-01 geodetic mark above sea level. Subtracting Eq. (17) from Eq. $\left(21^{\prime}\right)$, we obtain the estimate as

$$
h_{\text {Seal }}=996.0-21.4=974.6 \mathrm{~m} .
$$

It is noted that NNSS translocation between L0 point and Asuka Station was made with a total of 46 satellite passes acquired during April 16-19, 1987. The pass geometry was ill-balanced for east-west direction with 2 west- and 44 eastgoing passes, but was well-balanced for north-south direction with 23 north- and 23 south-going passes, within a resultant error of $1 \mathrm{~m}$ for latitudinal positioning. Although formal error for height difference calculated by using a GP1S software (JMR Instruments Inc., 1982) indicated $0.52 \mathrm{~m}$, simulation test of absolute error in Tokyo as a function of accepted satellite passes (Shibuya and Kitazawa, 1986) indicates worse error of $1 \mathrm{~m}$ for our translocation. As for one-frequency GPS relative positioning between Asuka Station and Seal Rock, the accuracy of each difference component in Eq. (20) can be considered as $6 \mathrm{~cm}$, respectively. Together with the error of $2 \mathrm{~cm}$ in the measurements of the antenna offsets, the overall accuracy of $h_{\text {Seal }}$ in Eq. (22) can be considered as $2 \mathrm{~m}$ as analogously obtained in Table 3.

The previous gravity datum for JAREs before the absolute gravity measurements was the value marked at the pier in the Earth Science Laboratory (ESL in Fig. 1; see Kaminuma et al., 1984) as

$$
g_{\text {ESL }, \text { old }}=982523.75 \text { mgal. }
$$

Using the gravity difference between the ESL and the IAGBN site (Fujiwara et al., 1994) of

$$
\Delta g=g_{\mathrm{ESL}}-g_{\mathrm{IAGBN}}=-0.276 \mathrm{mgal},
$$

new gravity standard at the ESL corresponding to Eq. (12) becomes

$$
g_{\text {ESL,new }}=982524.051 \mathrm{mgal} \text {. }
$$

Thus the gravity values in Dronning Maud Land obtained by Fukuda (1986), which referred to the old datum of Eq. (23), can be adjusted to the IAGBN gravity standard Eq. (25), by adding $0.301 \mathrm{mgal}$, as summarized in Table 4 . The freeair gravity anomalies can be calculated as similarly obtained at Syowa Station. With revised station coordinates and the elevations above sea level, the associated errors are estimated to be less than 1 mgal.

\section{Comparison with Gravity Anomaly Maps}

The obtained ground data of free-air gravity anomalies in the lower part of Table 2 and Table 4 can be used as test data for contouring the satellite altimeter derived gravity anomaly maps (e.g. Sandwell, 1992) or for contouring the coastal 

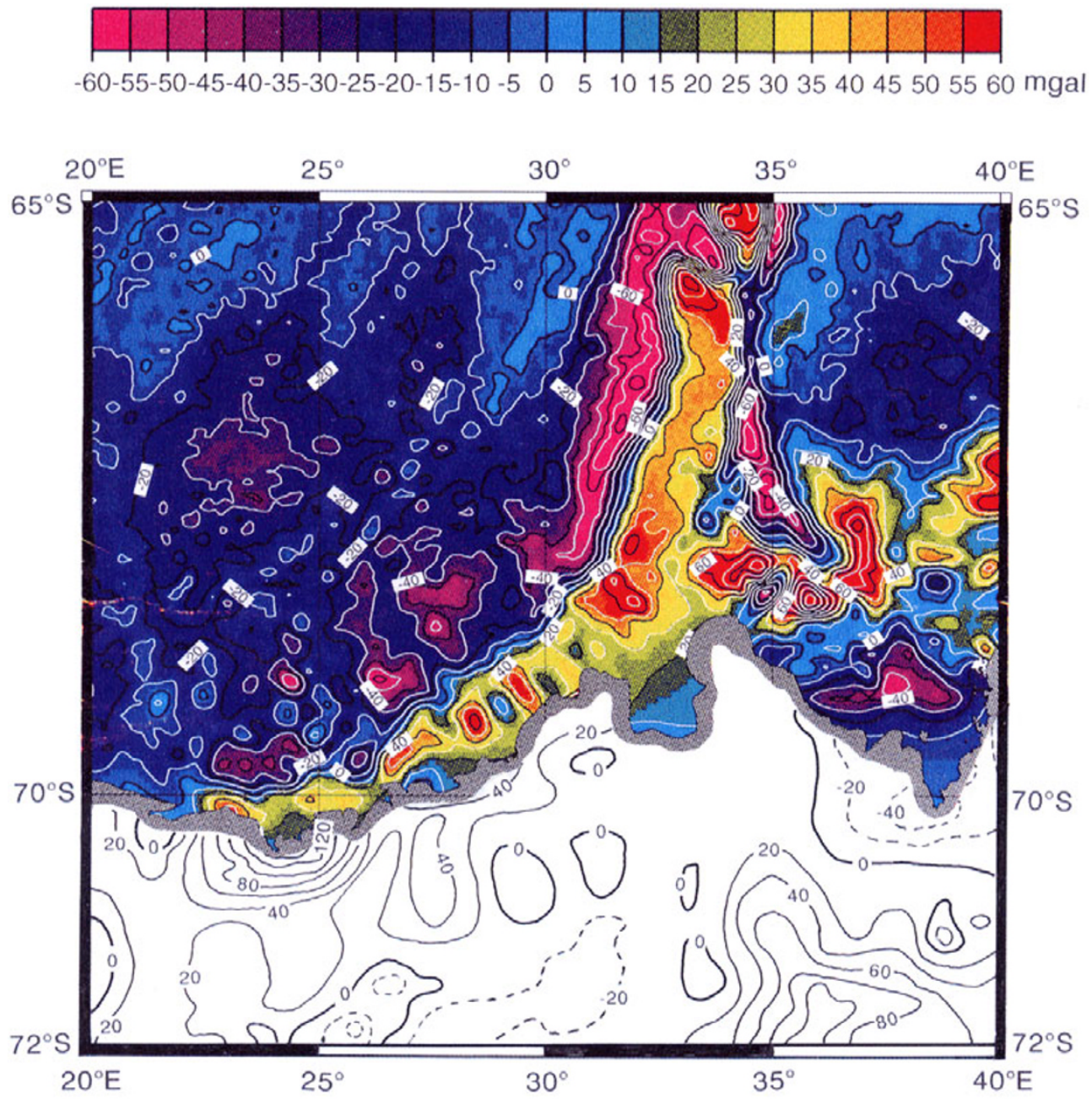

Contour: $20 \mathrm{mgal}$

Fig. 5. Free-air gravity anomaly map of the region bounded by $\left(20^{\circ} \mathrm{E}-40^{\circ} \mathrm{E}, 65^{\circ} \mathrm{S}-72^{\circ} \mathrm{S}\right)$. Combined from Sandwell (1992) for the colored sea area and Fukuda et al. (1990) for the contoured land area. Color legend is $5 \mathrm{mgal}$ interval, while contouring is 20 mgal interval. Thick solid curve is 0 mgal, thin solid curves for positive areas and thin broken curves for negative areas.

ice zone gravity anomaly maps with the merged data of the surface ship gravimeter and land traverse gravity survey (e.g. Fukuda et al., 1990).

For example, Fig. 5 illustrates the free-air gravity anomaly map of the $20^{\circ} \mathrm{E}-40^{\circ} \mathrm{E}$ by $65^{\circ} \mathrm{S}-72^{\circ} \mathrm{S}$ area, which was combined and edited from the above two maps. Around the Syowa Station area, the contouring is consistent with the ground data within a small bias of 2-3 mgals; the probable error is within the 5-7 mgal rms error of the GEOSAT gravity anomaly (Sandwell, 1992). In Breid Bay, Fukuda et al. (1990) indicated a local free-air gravity anomaly high of up to $120 \mathrm{mgal}$. The traverse gravity survey along L-Route in 1987 (Shibuya et al., 1991) and the $1 \mathrm{mgal}$ accuracy ground data at both ends of the L-Route (Table 4) may moderately (20-30 mgal) revise the contouring in this region.

\section{Conclusion}

As compared with its huge extent of land ice mass, Antarctica still has few geoid height and free-air gravity anomaly data with reliable error budget. We obtained ground data of 20-30 cm accuracy observed geoid height at Syowa Station $(22.37 \mathrm{~m})$ on the WGS84 ellipsoid. The OSU91A geoid model has a discrepancy of $58 \mathrm{~cm}$ as compared with the observed value, while the EGM96 model has a discrepancy of $27 \mathrm{~cm}$. Both the above geoid models have errors of $60-80 \mathrm{~cm}$ with a cumulative rms error (to the degree 360) of $49 \mathrm{~cm}$ for the OSU91A model (Rapp et al., 1991) or of $36 \mathrm{~cm}$ for the EGM96 model (Lemoine et al., 1997) and another 20-30 cm truncation errors of the higher-order harmonics. The Syowa data can be used as good test data for generating higher-order ( $n, m \geq 360)$ geopotential coefficient models. Although the Seal Rock data $(21.4 \mathrm{~m})$ has an uncertainty of $1.8 \mathrm{~m}$, it will also aid geopotential model fitting.

With the establishment of the IAGBN standard value at Syowa Station and gravimetric connection to the Dronning Maud Land region, the free-air gravity anomaly ground data of 0.05 mgal accuracy $(-18.64$ mgal at Syowa IAGBN station) and $1 \mathrm{mgal}$ accuracy $(-15.5 \mathrm{mgal}$ at Asuka Station 
and 134.4 mgal at L0 point) were obtained. These data will also serve as good data for adjusting the contouring of the satellite- and/or shipborne-derived free-air gravity anomaly maps in the region concerned.

Acknowledgments. The authors thank JARE members who supported installation of geoid height and gravity control stations, especially to Y. Fukuda and Asuka wintering staffs of JARE-28, and N. Seama of JARE-30. They are also indebted to Y. Fukuda (Kyoto Univ.), R. H. Rapp (Ohio State Univ.), D. Milbert (NOAA/NGS) and N. Pavlis (Hughes STX Corp.) for reviewing the early version of the manuscript. They also thank R. Forsberg (Geodetic Division, KMS) and M. Vermeer (Finnish Geodetic Institute) for critically reviewing, and $\mathrm{K}$. Boelling for checking the formulas and derivations in the manuscript. Ms. K. Hori helped the authors to prepare the manuscript.

\section{References}

Abusali, P. A. M., B. E. Schutz, B. D. Tapley, and M. Bevis, Transformation between SLR/VLBI and WGS-84 reference frames, Bull. Geod., 69, 6172, 1995.

Boedecker, G., Absolute gravity observation documentation standards, Bull. d'Inform., BGI, 68, 76-78, 1991.

Boedecker, G. and T. Fritzer, International Absolute Gravity Basestation Network, Status Report March 1986. International Association of Geodesy Special Study Group 3.87, Veröffentlichungen der Bayerischen Kommission für die Internationale Erdmessung der Bayerischen Akademie der Wissenschaften, Heft Nr. 47, 68 pp., 1986.

Boucher, C., Z. Altamimi, M. Feissel, and P. Sillard, Results and Analysis of the ITRF94, IERS Technical Notes, 20, Central Bureau of IERS Observatoire de Paris, France, 198 pp., 1996.

Defense Mapping Agency, Department of Defense World Geodetic System 1984: Its definition and relationship with local geodetic system, DMA Tech. Rep. 8350.2, 110 pp., Washington, D.C., 1987.

Fujiwara, S., K. Watanabe, and Y. Fukuda, Measurements of absolute gravity at Syowa Station, Antarctica, Bull. Geograph. Surv. Inst., 40, 1-5, 1994.

Fukuda, Y., Gravimetric connection between Asuka Camp and Syowa Station, and gravity survey on Rundvågshetta, Nankyoku Shiryo (Antarct. Rec.), 30, 164-174, 1986 (in Japanese).

Fukuda, Y., J. Segawa, and K. Kaminuma, Geoidal undulation and gravity anomaly around the Japanese Antarctic stations estimated from both satellite altimeter data and surface gravity data, Proc. NIPR Symp. Antarct. Geosci., 4, 108-118, 1990.

Golynsky, A. V., V. N. Masolov, Y. Nogi, K. Shibuya, C. Tarlowsky, and P. Wellman, Magnetic anomalies of Precambrian terranes of the East Antarctic shield coastal region $\left(20^{\circ} \mathrm{E}-50^{\circ} \mathrm{E}\right)$, Proc. NIPR Symp. Antarct. Geosci., 9, 24-39, 1996.

JMR Instruments Inc., GP-1S Program Suite, an Overview and Operator's Manual. JMR Document 2003500, Catsworth, CA, USA, 9 pp., 1982.

Kaminuma, K. and K. Tsukahara, Absolute gravity value measured at Syowa
Station, Antarctica, p. 32, Program and Abstracts of the International Symposium on Gravity, Geoid and Marine Geodesy 1996 (GraGeoMar96), September 30-October 5, University of Tokyo, Tokyo, Japan, 1996.

Kaminuma, K., K. Abe, and H. Tanaka, Leveling and gravity surveys at Syowa Station, Antarctica, Nankyoku Shiryo (Antarct. Rec.), 83, 62-74, 1984 (in Japanese).

Kanao, M., K. Shibuya, K. Watanabe, S. Fujiwara, H. Ikeda, and K. Okano, A note on geodetic ties among several reference points by different space geodetic techniques at Syowa Station, Antarctica, J. Geod. Soc. Jpn., 41, 357-364, 1995.

Lemoine, F. G., D. E. Smith, R. Smith, L. Kunz, E. C. Pavlis, N. K. Pavlis, S. M. Klosko, D. S. Chinn, M. H. Torrence, R. G. Williamson, C. M Cox, K. E. Rachlin, Y. M. Wang, S. C. Kenyon, R. Salman, R. Trimmer, R. H. Rapp, and R. S. Nerem, The development of the NASA GSFC and NIMA Joint Geopotential Model, IAG Sympo. No. 117, "Gravity, Geoid and Marine Geodesy”, Springer-Verlag, pp. 461-469, 1997.

McCarthy, D. D. (ed.), IERS Standards (1992), IERS Technical Note 13, 150 pp., Observatoire de Paris, 1992.

Moritz, H., Geodetic Reference System 1980, Bull. Geod., 54, 395-405, 1980 .

Odamaki, M., Y. Michida, I. Noguchi, Y. Iwanaga, S. Ikeda, and K. Iwamoto, Mean sea-level observed at Syowa Station, East Antarctica, Proc. NIPR Symp. Antarct. Geosci., 5, 20-28, 1991.

Rapp, R. H., Use of potential coefficient models for geoid undulation determinations using a spherical harmonic representation of the height anomaly/geoid undulation difference, J. Geod., 71, 282-289, 1997.

Rapp, R., Y. M. Wang, and N. K. Pavlis, The Ohio State 1991 geopotential and sea surface topography harmonic coefficient model, Rep. No. 410, Dep. Geod. Sci. and Surv., The Ohio State Univ., 94 pp., 1991.

Sandwell, D. T., Antarctic marine gravity field from high-density satellite altimetry, Geophys. J. Int., 109, 437-448, 1992.

Shibuya, K. and Y. Kitazawa, NNSS translocation test in the Kanto District with special application to Antarctic research program, Mem. Natl. Inst. Polar Res., Spec. Issue, 43, 23-36, 1986.

Shibuya, K., Y. Fukuda, and Y. Michida, Determination of geoid height at Breid Bay, East Antarctica, J. Geophys. Res., 96, B11, 18285-18294, 1991.

Takenaka, J., M. Yanagisawa, R. Fujii, and K. Shibuya, Crustal magnetic anomalies in the Antarctic region detected by MAGSAT, J. Geomag. Geoelectr., 43, 525-538, 1991.

Tobita, M., Coordinate transformation between terrestrial reference frames, Abstracts of 1997 Japan Earth and Planetary Science Meeting, p. 296, 1997 (in Japanese).

Yamamoto, H., Gravity measurements with the portable absolute gravimeter FG5 at Antarctica, Bull. Geograph. Surv. Inst., 42, 18-22, 1996 (in Japanese).

K. Shibuya (e-mail: shibuya@nipr.ac.jp), K. Doi (e-mail: doi@nipr. ac.jp), and S. Aoki (e-mail: shigeru@nipr.ac.jp) 